\title{
MYCELIAL GROWTH AND SPORULATION OF FUSARIUM SPP. PATHOGENIC TO ILEX PARAGUARIENSIS IN DIFFERENT CULTURE MEDIA AND UNDER EXPOSURE TO DIFFERENT LIGHT LEVELS.
}

\author{
Crescimento micelial e esporulação de Fusarium spp. patogênico a Ilex paraguariensis em diferentes meios de cultura e niveis de \\ luminosidade
}

\author{
Ricardo Mezzomo ${ }^{1}$; Jéssica Mengue Rolim${ }^{1}$; Tales Poletto ${ }^{1}$; Marília Boff de Oliveira² ${ }^{2}$ Marília Lazarotto ${ }^{3}$, Marlove Fátima \\ Brião Muniz ${ }^{4}$.
}

\begin{abstract}
1Programa de Pós-Graduação em Engenharia Florestal; Centro de Ciências Rurais, Universidade Federal de Santa Maria; e-mail (mezzomoricardo@hotmail.com)

2 Programa de Pós-Graduação em Engenharia Agrícola; Centro de Ciências Rurais, Universidade Federal de Santa Maria;

3 Departamento de Horticultura e Silvicultura; Universidade Federal do Rio Grande do Sul;

4 Departamento de Defesa Fitossanitária; Centro de Ciências Rurais, Universidade Federal de Santa Maria
\end{abstract}

Artigo enviado em 16/10/2017, aceito em 31/01/2018 e publicado em 10/04/2018.

\begin{abstract}
The aim of this study was to evaluate the effect of different culture media and light levels on mycelial growth and sporulation of Fusarium spp. pathogenic Ilex paraguariensis plants. For the tests, one isolate of F. oxysporum and six isolates of F. solani, were transfected with the following culture media: potato dextrose agar (PDA), potato-sucrose agar (PSA), malt extract agar (MEA) and V8. They were exposed to three light levels: 0, 12 and 24h of white light. The V8 and MEA culture media promoted the growth in diameter of the colonies, while the MEA and BSA media contributed to the sporulation of Fusarium spp.
\end{abstract}

Key-words - yerba-mate, photoperiod, fungus

Resumo - O objetivo deste trabalho foi avaliar o efeito de diferentes meios de cultura e níveis de luminosidade no crescimento micelial e esporulação de isolados de Fusarium spp. patogênicos a Ilex paraguariensis. Para os testes foram utilizados um isolado de F. oyxsporum e 6 isolados de F. solani. Os isolados foram transferidos para placas de Petri contendo os seguintes meios de cultura: BDA, BSA, MEA e V8, em seguida, foram submetidos a três níveis de luminosidade: 0 , 12 e $24 \mathrm{~h}$ de luz branca. Os meios V8 e MEA beneficiaram o crescimento em diâmetro das colônias já o MEA e BSA contribuíram para a esporulação de Fusarium spp.

Palavras chave - erva-mate, fotoperíodo, fungo

\section{INTRODUCTION}

The yerba mate (Ilex paraguariensis) is a crop of great importance in the states of the southern region and Mato Grosso do Sul, Brazil. Its consumption, in the form of cold (terere) tea or or hot tea (mate tea or chimarrão), is part of the popular culture of these states, as well as of countries like Argentina, Chile, Paraguay and Uruguay (Duboc, 2015). However, the entire production chain (from seed production to productive herbs) is subject to attack by pathogens, such as fungi of the genus Fusarium, causing root rot. In the nurseries, between 40 and $60 \%$ of the pre-field seedlings present symptoms of rot in the root system. Moreover, in adult herbs, root rot results in a reduction in productivity and, consequently, death of plants (Poletto et al 2006, Poletto et al 2015).
In plants, carbohydrate sources may be available in complex molecules requiring the transformation into low molecular weight sugars before being absorbed by phytopathogenic fungi. It is known that phytopathogens exhibit variations according to the use of different media with carbohydrate sources. Thus, studies on nutritional patterns and factors influencing fungal growth are needed as a basis for understanding the host-pathogen relationship. Yet, the necessary attention has not been given to the cultural parameters in vitro (culture media and luminosity) of the pathogens (Koley and Mahapatra, 2015).

In Phytopathology, after the isolation of the fungus, in vitro under controlled conditions, most often field activities, and the mass production of live conidia are fundamental for the development of this research stage, as a contribution to obtaining the results (Leão et al., 2012). 
In view of the above, this work aims to evaluate the effect of different culture media and luminosity levels on mycelial growth and sporulation in isolates of Fusarium spp. pathogenic Ilex paraguariensis.

\section{MATERIAL AND METHODS}

The experiment was carried out at the Elocy Minussi Plant Pathology Laboratory of the Rural Sciences
Center of the Federal University of Santa Maria, Santa Maria, RS. For the tests, a F. oxysporum (I6AR2) and six isolates of F. solani (I1AR1, I8AR1, M3AR2, M4, M5AR2 and $\mathrm{M} 7 \mathrm{C} 1)$ pathogenic to mate were used. The morphological and molecular characterization of the Fusarium spp. and the pathogenicity test in mate grass seedlings are described in Mezzomo (2017). The origin of the isolates is shown in Table 1.

Table 1 - Areas for the collection of Fusarium spp. pathogenic to mate.

\begin{tabular}{cccccc}
\hline Isolate & Collection date & Region & Coordinates (GMS) & ITS access * & TEF-1 $\alpha$ access * \\
\hline I1AR1 & January/2015 & Ilópolis & $-28^{\circ} 55^{\prime} 42,5^{\prime \prime} \mathrm{S},-52^{\circ} 08^{\prime} 32,6^{\prime \prime} \mathrm{W}$ & MF314188 & MF314145 \\
I6AR2 & January/2015 & Ilópolis & $-28^{\circ} 53^{\prime} 58,1^{\prime \prime} \mathrm{S},-52^{\circ} 04^{\prime} 48,0^{\prime \prime} \mathrm{W}$ & KX844995 & MF318446 \\
I8AR1 & January/2015 & Ilópolis & $-28^{\circ} 55^{\prime} 48,6^{\prime \prime} \mathrm{S},-52^{\circ} 10^{\prime} 40,1^{\prime \prime} \mathrm{W}$ & MF319519 & MF318442 \\
\hline M3AR2 & March/2015 & Machadinho & $-27^{\circ} 32^{\prime} 46,6^{\prime \prime} \mathrm{S},-51^{\circ} 40^{\prime} 47,7^{\prime \prime} \mathrm{W}$ & MF319521 & MF318443 \\
M4 & March/2015 & Machadinho & $-27^{\circ} 32^{\prime} 45,9^{\prime \prime} \mathrm{S},-51^{\circ} 40^{\prime} 48,1^{\prime \prime} \mathrm{W}$ & $\mathrm{MF} 319520$ & MF318444 \\
M5AR2 & March/2015 & Machadinho & $-27^{\circ} 32^{\prime} 16,1^{\prime \prime} \mathrm{S},-51^{\circ} 42^{\prime} 32,4^{\prime \prime} \mathrm{W}$ & $\mathrm{MF319522}$ & MF318445 \\
M7C1 & March/2015 & Machadinho & $-27^{\circ} 33^{\prime} 25,0^{\prime \prime} \mathrm{S},-51^{\circ} 40^{\prime} 04,2^{\prime \prime} \mathrm{W}$ & $\mathrm{MF319523}$ & MF318441 \\
\hline
\end{tabular}

(*)GenBank Access Code.

The culture media tested for mycelial growth and sporulation were: Potato-dextrose agar (BDA) (extract of $200 \mathrm{~g}$ of potato, $20 \mathrm{~g}$ of dextrose, $20 \mathrm{~g}$ of agar, $1000 \mathrm{ml}$ of distilled water), Potato-sucrose agar BSA (Extract of $200 \mathrm{~g}$ of potato, $20 \mathrm{~g}$ of sucrose, $20 \mathrm{~g}$ of agar and $1000 \mathrm{ml}$ of distilled water), Extract MEA (25 g of malt extract, $20 \mathrm{~g}$ of agar and $1000 \mathrm{ml}$ of distilled water), V8 (170 mL of Campbell Soup Co. V8 vegetable juice, $20 \mathrm{~g}$ of agar, $1.5 \mathrm{~g}$ of $\mathrm{CaCO}_{3}$ and $830 \mathrm{~mL}$ of distilled water).

The luminosity levels tested for mycelial growth and sporulation were: continuous darkness (0h), a photoperiod of 12 hours of white light (12h) and continuous white light (24h).

The evaluation of the mycelial growth consisted of the measurement of the diameter of the colony produced in the Petri dish at seven days, in two diametrically opposite directions, with the aid of a digital caliper. Four plates were evaluated per isolate and culture

\section{RESULTS AND DISCUSSION}

When analyzing the mean values of the three luminosity regimes within each culture medium (photoperiod vs media), mean and light interaction were observed for all isolates for the variables mycelial growth and sporulation.

For mycelial growth of the I1AR1 isolate (Table 2 ) the 12 and 24 hours luminosity levels differed statistically. In the case of 12 hours the highest growth was observed in the V8 medium $(69.90 \mathrm{~mm})$ but did not differ statistically from the MEA, with a mean value of 67.88 $\mathrm{mm}$. For the exposure under continuous light $(24 \mathrm{~h})$ the medium. The mean growth of each isolate was determined and the results were presented in millimeters $(\mathrm{mm})$.

Sporulation was evaluated using three Petri dishes for each isolate grown in different culture media, which were incubated for a period of seven days in BOD at 24C. After this period, $20 \mathrm{ml}$ of sterile distilled water was added to the plates and, after scraping the colony with Drigalski's loop, the spore suspension was filtered in a double layer of gauze. The concentration of the spore suspension was determined by the use of an light microscope with the aid of the Neubauer chamber.

The trials were arranged in a completely randomized design, with five replicates, each using a Petri dish. The mycelial growth and sporulation capacity data were analyzed as a factorial experiment (4X3 - culture media and luminosity levels). The means were compared using the Tukey test $(\mathrm{p} \leq 0.05)$. The SISVAR program was used for statistical analyzes (FERREIRA, 2008).

mean mycelial growth in the V8 culture medium $(68.30 \mathrm{~mm})$ did not differ statistically from the MEA and BSA media with a mean of 62.81 and $59.47 \mathrm{~mm}$, respectively. When incubated in the dark there was no difference in mycelial growth between the studied media. When analyzing the half-photoperiod interaction photoperiod vs media, only the BDA medium differed statistically.

However, the mycelial growth of the I6AR2 isolate did not show statistical difference between the different photoperiods nor between the different culture 
media. Still, it was possible to observe that there is good mycelial growth both in the different culture media and in the different levels of luminosity, since only in the $\mathrm{BDA} / 12 \mathrm{~h}$ medium, the colony diameter mean value was below $72.40 \mathrm{~mm}$.

For the mycelial growth of the I8AR1 isolate only the photoperiod $\mathrm{Oh}$ did not differ statistically in the different media, with mean values ranging from 55.40 to $61.42 \mathrm{~mm}$. At the three levels of lightness tested, the lowest mean values were observed in the BDA, from 47.58 (12h) to $57.14 \mathrm{~mm}$ (24h). The photoperiod vs medium ratio, half only in BSA medium, did not differ statistically.

Table 2 - Mycelial growth (mm) of Fusarium spp. measured at seven days at different levels of luminosity in hours (h) and culture media.

\begin{tabular}{|c|c|c|c|c|c|}
\hline \multirow{2}{*}{$\begin{array}{l}\text { Isolates } \\
\text { I1AR1 }\end{array}$} & \multicolumn{4}{|c|}{ Culture media } & \multirow[b]{2}{*}{ C.V. $(\%)$} \\
\hline & $\mathrm{BDA}$ & MEA & V8 & BSA & \\
\hline $0 \mathrm{~h}$ & $56.52 \mathrm{a}^{*} \mathrm{~A}^{*}$ & 59.22 a A & $66.29 \mathrm{a} \mathrm{A}$ & 59.05 a A & \\
\hline $12 \mathrm{~h}$ & 45.49 с B & $67.88 \mathrm{ab} \mathrm{A}$ & $69.90 \mathrm{a} \mathrm{A}$ & $58.98 \mathrm{~b} \mathrm{~A}$ & 6,94 \\
\hline $24 \mathrm{~h}$ & $56.85 \mathrm{~b} \mathrm{~A}$ & $62.81 \mathrm{ab} \mathrm{A}$ & $68.30 \mathrm{a} \mathrm{A}$ & $59.47 \mathrm{ab} \mathrm{A}$ & \\
\hline \multicolumn{6}{|c|}{ Culture media } \\
\hline I6AR2 & BDA & MEA & $\mathrm{V} 8$ & BSA & \\
\hline $0 \mathrm{~h}$ & 74.83 a A & $74.87 \mathrm{a} \mathrm{A}$ & $72.40 \mathrm{a} \mathrm{A}$ & $75.13 \mathrm{a} \mathrm{A}$ & \\
\hline $12 \mathrm{~h}$ & 67.46 a A & $75.42 \mathrm{a} \mathrm{A}$ & 73.91 a A & 76.47 a A & 3,87 \\
\hline $24 \mathrm{~h}$ & $74.40 \mathrm{a} \mathrm{A}$ & $73.44 \mathrm{a} \mathrm{A}$ & $71.24 \mathrm{a} \mathrm{A}$ & 74.81 a A & \\
\hline \multicolumn{6}{|c|}{ Culture media } \\
\hline I8AR1 & $\mathrm{BDA}$ & MEA & V8 & BSA & \\
\hline $0 \mathrm{~h}$ & $55.40 \mathrm{a} \mathrm{AB}$ & 60.90 a B & 61.42 a B & 57.79 a A & \\
\hline $12 \mathrm{~h}$ & 47.58 c B & $71.90 \mathrm{ab} \mathrm{A}$ & 76.82 a A & $61.94 \mathrm{~b} \mathrm{~A}$ & 7,81 \\
\hline $24 \mathrm{~h}$ & $57.14 \mathrm{~b} \mathrm{~A}$ & $67.84 \mathrm{a} \mathrm{AB}$ & $71.06 \mathrm{a} \mathrm{A}$ & $60.80 \mathrm{ab} \mathrm{A}$ & \\
\hline \multicolumn{6}{|c|}{ Culture media } \\
\hline M3AR2 & $\mathrm{BDA}$ & MEA & V8 & BSA & \\
\hline $0 \mathrm{~h}$ & $61.40 \mathrm{~b} \mathrm{~A}$ & $72.70 \mathrm{a} A$ & $73.66 \mathrm{a} \mathrm{A}$ & $68.47 \mathrm{ab} \mathrm{A}$ & 14,71 \\
\hline $12 \mathrm{~h}$ & $53.06 \mathrm{~b} \mathrm{~A}$ & 69.91 a A & $71.15 \mathrm{a} \mathrm{A}$ & 70.12 a A & \\
\hline $24 \mathrm{~h}$ & $59.40 \mathrm{~b} \mathrm{~A}$ & 70.31 a A & 72.83 a A & 71.96 a A & \\
\hline \multicolumn{6}{|c|}{ Culture media } \\
\hline M4 & BDA & MEA & V8 & BSA & \\
\hline $0 \mathrm{~h}$ & $63.50 \mathrm{~b} \mathrm{~A}$ & $64.51 \mathrm{ab} \mathrm{A}$ & 74.17 a A & $66.96 \mathrm{ab} \mathrm{A}$ & \\
\hline $12 \mathrm{~h}$ & $50.81 \mathrm{~b} \mathrm{~B}$ & 70.94 a A & 78.85 a A & 70.84 a A & 6,98 \\
\hline $24 \mathrm{~h}$ & $61.12 \mathrm{~b} \mathrm{~A}$ & $70.54 \mathrm{ab} \mathrm{A}$ & $72.57 \mathrm{a} \mathrm{A}$ & $63.33 \mathrm{ab} \mathrm{A}$ & \\
\hline \multicolumn{6}{|c|}{ Culture media } \\
\hline M5AR2 & $\mathrm{BDA}$ & MEA & $\mathrm{V} 8$ & BSA & \\
\hline $0 \mathrm{~h}$ & $48.90 \mathrm{~b} \mathrm{~A}$ & $73.13 \mathrm{a} \mathrm{A}$ & $73.11 \mathrm{a} \mathrm{A}$ & $63.43 \mathrm{a} \mathrm{A}$ & \\
\hline $12 \mathrm{~h}$ & $50.24 \mathrm{~b} \mathrm{~A}$ & $67.20 \mathrm{a} \mathrm{A}$ & $68.93 \mathrm{a} A$ & $64.62 \mathrm{aA}$ & 11,39 \\
\hline $24 \mathrm{~h}$ & $44.54 \mathrm{~b} \mathrm{~A}$ & $40.82 \mathrm{~b} \mathrm{~A}$ & $70.32 \mathrm{a} \mathrm{A}$ & $44.49 \mathrm{~b} \mathrm{~B}$ & \\
\hline \multicolumn{6}{|c|}{ Culture media } \\
\hline M7C1 & $\mathrm{BDA}$ & MEA & V8 & BSA & \\
\hline $0 \mathrm{~h}$ & $58.43 \mathrm{~b} \mathrm{~A}$ & $68.35 \mathrm{ab} \mathrm{A}$ & $71.42 \mathrm{a} \mathrm{A}$ & 70.09 a $\mathrm{A}$ & \\
\hline $12 \mathrm{~h}$ & $52.90 \mathrm{~b} \mathrm{AB}$ & $65.71 \mathrm{a} \mathrm{AB}$ & 74.81 a A & 68.16 a A & 7,54 \\
\hline $24 \mathrm{~h}$ & 48.70 a B & $56.55 \mathrm{a} \mathrm{A}$ & 58.73 a B & 50.46 a B & \\
\hline
\end{tabular}

* Means followed by the same upper case letter within the same column and the same lower case letter within the same row do not differ by Tukey test at

$5 \%$ significance Where: BDA: potato-dextrose-agar, MEA: malt-agar extract; BSA: potato-sucrose-agar and CV: coefficient of variation. 


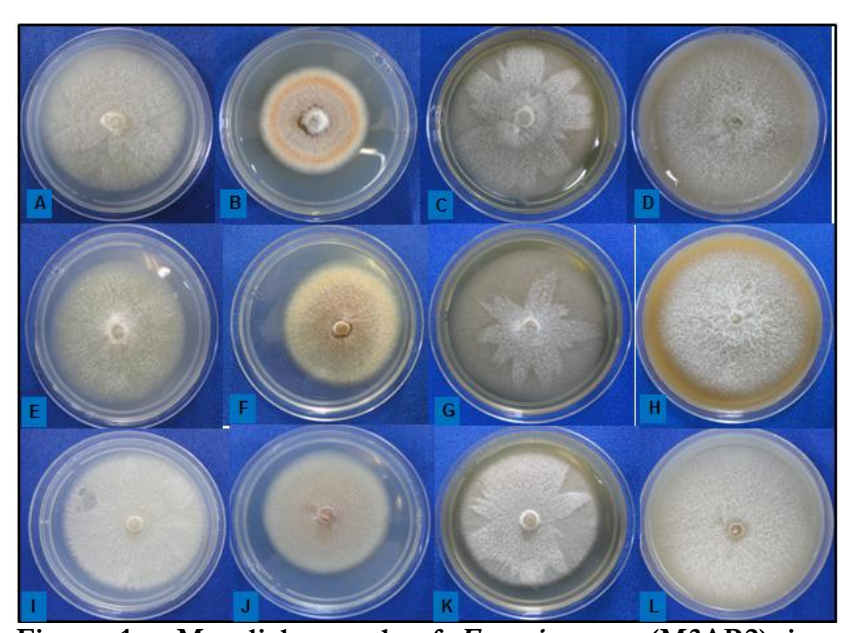

Figure 1 - Mycelial growth of Fusarium sp (M3AR2) in different media and under different light levels. (A): BSA / 12h; (B): BDA / 12h; (C): MEA / 12h; (D): V8 / 12h; (E): BSA / 0h; (F): BDA / 0h; (G): MEA / 0h; (H): V8 / 0h; (I): BSA / 24h; (J): BDA / 24h; (K): MEA / 24h; (L): V8 / 24h.

Also in Table 2, the M3AR2 isolate showed the lowest mycelial growth when grown in the BDA medium, independently of the photoperiod, differing statistically from the other media (except BSA 0h). However, the others did not differ statistically in the three light levels tested. At the interaction levels of luminosity vs culture media, none of the simulations tested differed statistically as to the culture medium used.

On the other hand, the M4 isolate when incubated in the dark in V8 medium obtained the highest mean in mycelial growth, with $74.17 \mathrm{~mm}$ in diameter, differing statistically only in the BDA medium, with a mean of $63.50 \mathrm{~mm}$. The same was observed with the 12 and $24 \mathrm{~h}$ levels, where the V8 obtained a mean of 78.85 and $72.57 \mathrm{~mm}$ and BDA of 50.81 and $61.12 \mathrm{~mm}$, respectively. Among the interaction levels of luminosity x culture media only the BDA medium with the $12 \mathrm{~h}$ photoperiod differed statistically from the others, presenting the lowest mycelial growth, with a mean of $50.81 \mathrm{~mm}$.

In the case of the M5AR2 isolate under the 0 and $12 \mathrm{~h}$ brightness levels, the mycelial growth behaved in a similar way, the highest means were obtained in the V8 medium that differed statistically only from BDA. The same was not observed at the $24 \mathrm{~h}$ level, where V8 differed statistically from the MEA, BSA and BDA media. For the interaction levels of luminosity $\mathrm{x}$ culture media only the BSA $24 \mathrm{~h}$ differed statistically from the other two levels tested.

At levels 0 and $12 \mathrm{~h}$ the mycelial growth of the M7C1 isolate was lower in the BDA medium, which differed statistically from the other media tested (except MEA 0h). However, in continuous light no statistical difference was observed in V8, MEA, BDA and BSA.

In general, when we only observe the mycelial growth, we see that for the isolates of Fusarium spp. pathogenic Ilex paraguariensis were the V8 and MEA media, which alternated the highest means among the tested luminosity levels. For Leão et al. (2012), the modified V8 medium provided the greater area of the colony of Ascochyta cucumis when submitted to the level of $0 \mathrm{~h}$ and a lower mean diameter when submitted to the level of $24 \mathrm{~h}$. Culture media that have extracts and juices from leaves or plant parts in their composition, such as V8, usually stimulate not only the mycelial growth but also the sporulation of various fungi (Dhingra and Sinclair, 1985).

As regards luminosity levels, it was observed that all of them favored the mycelial growth of the isolates. According to Teixeira et al. (2001) the growth in vitro in F. oxysporum f.sp. vasinfectum was considerably higher when incubated in continuous darkness. However, according to these authors, the mycelial growth of F. moniliforme was not influenced by the presence or absence of light sources. Lazarotto et al. (2013) found that BSA provided higher means for mycelial growth of F. chlamydosporum. According to the same authors, the continuous darkness disfavored the diameters of the F. chlamydosporum. Similar results were reported by Silva and Teixeira (2012), where the absence of light inhibited the growth of F. solani. As regards culture media, these authors corroborate with the results of Lazarotto et al. (2013), since the BSA and BDA presented the highest means in the diameters of the colonies of $F$. solani

In the isolated I1AR1 the best sporulation rates (Table 3) were detected in the MEA medium under the three levels of luminosity tested (4.34 to $5.60 \times 10^{6}$ spores $/ \mathrm{mL}$ ). When compared at $24 \mathrm{~h}$ the means did not differ statistically. In the interaction of luminosity levels vs methods only in the V8 medium was it possible to observe statistical difference between the means, where the light continues to differ statistically from the other levels of luminosity.

In contrast, the MEA medium did not favor sporulation of the I6AR2 isolate when compared to the means in the three photoperiods tested. Yet, it did not differ statistically from the BDA means. The means of the photoperiod $\mathrm{x}$ medium interaction did not differ statistically in MEA and V8 media. BSA medium favored sporulation in treatments BSA $0 \mathrm{~h}$ and BSA $12 \mathrm{~h}$. The means presented little variation: 5,55 and 5,70 x $10^{6}$ spores/mL, respectively.

The sporulation means of the I8AR1 isolate did not differ statistically using the different levels of luminosity and culture media.

The continuous light most favored the sporulation of the M3AR2 isolate, presenting promising means when cultured in BSA medium, but these did not differ statistically from the MEA. The worst means of sporulation of this isolate were obtained in V8 medium.

The M4 isolate when incubated in continuous light showed no statistical difference for the sporulation variable. For this isolate the MEA $0 \mathrm{~h}$ treatment obtained 
the highest sporulation index $\left(7.44 \times 10^{6}\right.$ spores $\left./ \mathrm{mL}\right)$. Among the culture media the only interaction photoperiod vs means where the means of sporulation differed statistically was the MEA.

Table 3 - Sporulation (x106 spores / $\mathrm{ml})$ of Fusarium spp. measured at seven days under different levels of luminosity in hours (h) and in different culture media.

\begin{tabular}{|c|c|c|c|c|c|}
\hline \multirow{2}{*}{$\begin{array}{l}\text { Isolates } \\
\text { I1AR1 }\end{array}$} & \multicolumn{4}{|c|}{ Culture media } & \multirow[b]{2}{*}{ C.V. $(\%)$} \\
\hline & BDA & MEA & $\mathrm{V} 8$ & BSA & \\
\hline $0 \mathrm{~h}$ & $2.21 \mathrm{bc}^{*} \mathrm{~A}^{*}$ & $5.60 \mathrm{a} \mathrm{A}$ & $1.52 \mathrm{c} \mathrm{B}$ & $3.73 \mathrm{ab} \mathrm{A}$ & \\
\hline $12 \mathrm{~h}$ & $3.55 \mathrm{ab} \mathrm{A}$ & $4.44 \mathrm{a} \mathrm{A}$ & $1.95 \mathrm{~b} \mathrm{~B}$ & $2.36 \mathrm{ab} \mathrm{A}$ & 20,69 \\
\hline \multirow[t]{2}{*}{$24 \mathrm{~h}$} & $3.61 \mathrm{a} \mathrm{A}$ & $4.34 \mathrm{a} \mathrm{A}$ & 2.86 a A & $2.95 \mathrm{a} \mathrm{A}$ & \\
\hline & \multicolumn{4}{|c|}{ Culture media } & \\
\hline I6AR2 & BDA & MEA & V8 & $\mathrm{BSA}$ & \\
\hline $0 \mathrm{~h}$ & $2.72 \mathrm{~b} \mathrm{AB}$ & $2.25 \mathrm{~b} \mathrm{~A}$ & $3.51 \mathrm{ab} \mathrm{A}$ & $5.55 \mathrm{a} \mathrm{B}$ & \\
\hline $12 \mathrm{~h}$ & $1.60 \mathrm{~b} \mathrm{~B}$ & $1.71 \mathrm{~b} \mathrm{~A}$ & 5.66 a A & $5.70 \mathrm{a} \mathrm{A}$ & 22,73 \\
\hline \multirow[t]{2}{*}{$24 \mathrm{~h}$} & $3.68 \mathrm{ab} \mathrm{A}$ & $2.44 \mathrm{~b} \mathrm{~A}$ & $3.73 \mathrm{ab} \mathrm{A}$ & $4.54 \mathrm{a} \mathrm{B}$ & \\
\hline & \multicolumn{4}{|c|}{ Culture media } & \\
\hline I8AR1 & BDA & MEA & $\mathrm{V} 8$ & BSA & \\
\hline $0 \mathrm{~h}$ & 3.46 a $\mathrm{A}$ & $3.20 \mathrm{a} \mathrm{A}$ & $3.35 \mathrm{a} \mathrm{A}$ & 4.82 a $\mathrm{A}$ & \\
\hline $12 \mathrm{~h}$ & $2.56 \mathrm{a} \mathrm{A}$ & $3.39 \mathrm{a} \mathrm{A}$ & $2.44 \mathrm{a} \mathrm{A}$ & $4.08 \mathrm{a} \mathrm{A}$ & 21,30 \\
\hline \multirow[t]{2}{*}{$24 \mathrm{~h}$} & $4.45 \mathrm{a} \mathrm{A}$ & $3.73 \mathrm{a} \mathrm{A}$ & 3.79 a A & 4.18 a A & \\
\hline & \multicolumn{4}{|c|}{ Culture media } & \\
\hline M3AR2 & BDA & MEA & V8 & BSA & \\
\hline $0 \mathrm{~h}$ & $2.94 \mathrm{a} \mathrm{A}$ & $3.20 \mathrm{a} \mathrm{B}$ & $2.90 \mathrm{a} \mathrm{A}$ & $3.75 \mathrm{a} \mathrm{B}$ & \\
\hline $12 \mathrm{~h}$ & $2.31 \mathrm{a} \mathrm{A}$ & $2.09 \mathrm{a} \mathrm{B}$ & 3.05 a A & 3.68 a B & 34,71 \\
\hline \multirow[t]{2}{*}{$24 \mathrm{~h}$} & $3.85 \mathrm{~b} \mathrm{~A}$ & $6.57 \mathrm{a} \mathrm{A}$ & $2.62 \mathrm{~b} \mathrm{~A}$ & 7.04 a A & \\
\hline & \multicolumn{4}{|c|}{ Culture media } & \\
\hline M4 & $\mathrm{BDA}$ & MEA & V8 & BSA & \\
\hline $0 \mathrm{~h}$ & $3.40 \mathrm{~b} \mathrm{~A}$ & $7.44 \mathrm{a} \mathrm{A}$ & $2.98 \mathrm{~b} \mathrm{~A}$ & $3.40 \mathrm{~b} \mathrm{~A}$ & \\
\hline $12 \mathrm{~h}$ & 4.85 a A & $1.39 \mathrm{~b} \mathrm{~B}$ & $1.70 \mathrm{~b} \mathrm{~A}$ & $3.09 \mathrm{ab} \mathrm{A}$ & 26,58 \\
\hline \multirow[t]{2}{*}{$24 \mathrm{~h}$} & $4.47 \mathrm{a} \mathrm{A}$ & $3.15 \mathrm{a} \mathrm{B}$ & 2.85 a A & $3.75 \mathrm{a} \mathrm{A}$ & \\
\hline & \multicolumn{4}{|c|}{ Culture media } & \\
\hline M5AR2 & $\mathrm{BDA}$ & MEA & V8 & BSA & \\
\hline $0 \mathrm{~h}$ & $2.32 \mathrm{~b} \mathrm{~B}$ & $4.61 \mathrm{a} \mathrm{A}$ & $1.90 \mathrm{~b} \mathrm{~B}$ & $3.58 \mathrm{ab} \mathrm{B}$ & \\
\hline $12 \mathrm{~h}$ & $3.70 \mathrm{a} B$ & $3.14 \mathrm{a} \mathrm{A}$ & 3.73 a $A B$ & $3.01 \mathrm{a} \mathrm{B}$ & 21,25 \\
\hline \multirow[t]{2}{*}{$24 \mathrm{~h}$} & $6.80 \mathrm{a} A$ & $4.79 \mathrm{ab} \mathrm{A}$ & $4.42 \mathrm{~b} \mathrm{~A}$ & $5.90 \mathrm{ab} \mathrm{A}$ & \\
\hline & \multicolumn{4}{|c|}{ Culture media } & \\
\hline M7C1 & $\mathrm{BDA}$ & MEA & V8 & BSA & \\
\hline $0 \mathrm{~h}$ & $3.61 \mathrm{~b} \mathrm{C}$ & $4.98 \mathrm{ab} \mathrm{B}$ & $5.55 \mathrm{ab} \mathrm{B}$ & $6.46 \mathrm{a} \mathrm{A}$ & \\
\hline $12 \mathrm{~h}$ & 5.88 a B & $3.64 \mathrm{~b} \mathrm{~B}$ & $4.21 \mathrm{ab} B$ & $2.68 \mathrm{~b} \mathrm{~B}$ & 23,01 \\
\hline $24 \mathrm{~h}$ & $8.27 \mathrm{a} \mathrm{A}$ & $8.53 \mathrm{a} \mathrm{A}$ & $9.32 \mathrm{a} \mathrm{A}$ & $4.91 \mathrm{~b} \mathrm{~A}$ & \\
\hline
\end{tabular}

* Means followed by the same upper case letter within the same column and the same lower case letter within the same row do not differ by Tukey test at 5\% significance. Where: BDA: potato-dextrose-agar, MEA: malt-agar extract; BSA: potato-sucrose-agar and CV: coefficient of variation.

Following Table 3, for the M5AR2 isolate the BDA medium showed the best means, especially the $24 \mathrm{~h}$ light level with a mean of $6.80 \times 10^{6}$ spores $/ \mathrm{ml}$. The V8/0h treatment obtained a low sporulation index with a mean of $1.90 \times 10^{6}$ spores $/ \mathrm{ml}$. The interaction level of luminosity vs MEA did not differ statistically.

In addition to the isolate M3AR2, the $24 \mathrm{~h}$ photoperiod was favorable to the sporulation of the M7C1 isolate when grown in V8, MEA and BDA media, where the means did not differ statistically. Moreover, in the photoperiod vs half interaction the sporulation values of the BDA medium differed statistically from each other, comparing the three photoperiods tested, and the use of light continued to provide greater sporulation.

For the sporulation variable, the MEA and BSA media were prominent. However, generally, all media tested provided nutrient concentrations and when combined with the physiology of the isolates provide satisfactory rates of sporulation mainly under continuous light exposure. Lazarotto et al. (2013) suggest the BSA and BDA media combined with continuous light levels for the mass production of macroconidia of $F$. chlamydosporum. Corroborating the results obtained in the present work, Silva and Teixeira (2012) state that carbohydrate-rich 
media such as BDA and BSA when incubated at $24 \mathrm{~h}$ level induce an increase in the production of conidia of $F$. solani. According to Camera et al. (2014), analyzing the growth and sporulation of Alternaria brasiliensis under different levels of light, the lowest number of conidia/ml is observed when the pathogen is cultivated in BDA. However, the same authors state that the level of continuous light presents the best means in the concentration of spores of $A$. brasiliensis.

Most fungi appear to be more suited to the daily regime, alternating periods between dark and light, following the typical pattern of nature. However, some light-sensitive fungi sporulate and/or grow under continuous light (TEIXEIRA et al., 2001).

\section{CONCLUSIONS}

The culture media most recommended for the growth of Fusarium spp. isolated from mate are V8 and MEA and for sporulation, MEA and BSA.

Independent of the culture medium, continuous light provided the highest spore $/ \mathrm{mL}$ concentration of Fusarium spp.

\section{ACKNOWLEDGEMENTS}

The authors thank the Coordination for Improvement of Higher Education Personnel (CAPES) for the granting of a doctoral scholarship to the first author and $\mathrm{CNPq}$ by the Research Productivity Exchange of the co-authors Marlove Fatima Brião Muniz.

\section{REFERENCES}

DUBOC, E. Erva-mate parâmetros para seleção de planta matriz e área de coleta de sementes. Documentos/ Embrapa Agropecuária Oeste, n. 132, p. 1-48, dez/2015.

CAMERA, J. N.; DEUNER, C. C.; DANELLI, A. L. D.; REIS, E. M. Desenvolvimento de Passalora sojinna em diferentes meios de cultura e regimes luminosos. Semina: Ciências Agrárias, v. 35, n. 4, p. 1793-1800, jul./ago. 2014.

DHINGRA, O. D.; SINCLAIR, J. B. Basic Plant Pathology Methods. Boca Raton: CRC-Press; Edição: 2nd ed, 1995.

FERREIRA, D.F. SISVAR: um programa para análises estatísticas e ensino de estatística. Revista Symposium, v.6, p.36-41, jul./dez. 2008.
KOLEY, S.; MAHAPATRA, S. S. Evaluation of culture media for growth characteristics of Alternaria solani, causing early blight of tomato. Plant Pathology \& Microbiology, v.1 n. 5, p. 1-5, 2015.

LEÃO, E.U.; SANTOS, G. R.; SARMENTO, R. A.; REIS, M. R.; CHAGAS JÚNIOR, A. F. Crescimento micelial e produção de conídios de Ascochyta cucumis em diferente meios de cultura e regimes de luz. Bioscience Journal, v. 28, n. 2, p. 325-331, mar./ apr. 2012.

LAZAROTTO, M.; MEZZOMO, R.; MACIEL, C. G.; FINGER, G.; MUNIZ, M.F.B. Mycelia growth and sporulation of Fusarium chlamydosporum species complex under different culture conditions. Revista Ciências. Agrárias, v. 57, n. 1, p. 35-40, jan./mar. 2014.

MEZZOMO, R. Caracterização morfofisiológica, molecular, enzimática e compatibilidade vegetativa de F. oxysporum e F. solani em erva-mate. 2017. 100f. Tese (Doutorado em Engenharia Florestal) - Universidade Federal de Santa Maria, Santa Maria, 2017.

POLETTO, I.; MUNIZ. M. F.B.; CECONI, D. E.; SANTIN, D.; WEBER, M. N. D.; BLUME, E. et al. Zoneamento e identificação de Fusarium spp. causador de podridão-de-raízes em plantios de erva-mate (Ilex paraguariensis A. St.-Hil.) na região do Vale do Taquarí-RS. Ciência Florestal, v. 16, n. 1, p. 1-10, 2006.

POLETTO, I.; MUNIZ, M. F. B.; CECONI, D. E.; POLETTO, T. Aspectos epidemiológicos da podridão-deraízes da erva-mate (Ilex paraguariensis). Ciência Florestal, v. 25, n. 1, abr./jun. 2015.

SILVA, J. L.; TEIXEIRA, R. N. V. Esporulação e crescimento micelial de Fusarium solani em diferentes meios de cultura e regimes de luminosidade. RevistaAgro@mbiente On-line, v. 6, n. 1, p. 47-52, jan./ apr. 2012.

SOARES, P. L. M.; NOZAKI, M. H.; BARBOSA, B. F. F.; SANTOS, J. M.; BARBOSA, J. C. Crescimento e esporulação de duas espécies de Arthrobotrys corda em diferentes meios de cultura e dois ambientes. Bioscience Journal, v. 25, n. 2, p.63-74, mar./apr. 2009.

TEIXEIRA, H.; CHITARRA, L. G.; ARIAS, S. M. S.; MACHADO, J. C. Efeito de diferentes fontes de luz no crescimento e esporulação in vitro de fungos fitopatogênicos. Ciência e agrotecnologia, Lavras, v.25, n.6, p.1314-1320, nov./dez. 2001. 